Relations industrielles

Industrial Relations

\title{
Labour Leaders in Study Session
}

\section{Marcel de la Sablonière}

Volume 4, numéro 3, novembre 1948

URI : https://id.erudit.org/iderudit/1023448ar

DOI : https://doi.org/10.7202/1023448ar

Aller au sommaire du numéro

Éditeur(s)

Département des relations industrielles de l'Université Laval

ISSN

0034-379X (imprimé)

1703-8138 (numérique)

Découvrir la revue

Citer cet article

de la Sablonière, M. (1948). Labour Leaders in Study Session. Relations

industrielles / Industrial Relations, 4(3), 23-25. https://doi.org/10.7202/1023448ar

Tous droits réservés (C Département des relations industrielles de l’Université Laval, 1948
Ce document est protégé par la loi sur le droit d'auteur. L'utilisation des services d'Érudit (y compris la reproduction) est assujettie à sa politique d'utilisation que vous pouvez consulter en ligne.

https://apropos.erudit.org/fr/usagers/politique-dutilisation/ 
As a matter of fact, all these dangers exist only in the measure that fear of them inspires an attitude of passivity in the officials. But, this is neither necessary nor inevitable. If the labour world, while respecting the freedom of the employer's initiative, makes sufficiently understood that it would welcome his efforts with favour, the employer's gesture would present itself as an answer which far from harming the unions would re-unite them in a common aspiration towards social peace. When there are wage demands and employers' compromises we are in a «liberal» regime. But, if the Labour world sees an aspiration which is dear to it freely satisfied by employers who are hoping to realize a community within the enterprise, unionism is then complete in its role of social progress - and we are in a Christian regime. This was well explained by Mr. Gérard Picard, President of C.C.C.L. (C.T.C.C.) in his inaugural speech at the Congress of 1948.

The undertaking of the study of reforms by the unions usually leads to their becoming the organization in the enterprise which carries out these ideas in co-operation with the direction. If the community of profit-sharing, sooner or later, calls on the committees of the enterprise it is evi- dent that only the union representation can give these latter a basis sufficiently competent and sufficiently mature. In such a case it is union watchfulness which permits the avoidance of mistakes between basic wage adjustments and the sharing of profits.

Thus the dangers of enterprise reform are serious only when the unionism is passive or hostile. With a progressive unionism reform can be the providential means of advancing definitely, in enterprise after enterprise, from bargaining to co-operation, from systematic opposition to systematic «composition», from laissez-faire enterprise to free entreprise. The unimpeded character of the employer's efforts and his outlook in matters of employer-employee co-operation virtually determines for those who wish to «construct a social edifice on the unshakeable centre of gravity of the Divine Law ${ }^{3}$ which of these reforms are the measures most apt to dispel the worker's mistrust which, in the last analysis, is the measure of managements' distrust. The Golden Rule here should serve as guiding principle. Love knows not fear.

(3) Pope Pius XII, Christmas Message 1942.

\title{
LABOUR LEADERS IN STUDY SESSION
}

\author{
MARCEL dE LA SABLonNière
}

Each week-end of last August saw the arrival at the Island of St. Ignace, from the principal industrial centres of the Province, of some forty or so labour leaders - official delegates from their respective unions.

The atmosphere. - From Friday evening to Sunday evening, at the conferences as in the discussion groups, in the casual conversations as in the evening forums, there was always the same sympathetic atmosphere whose perfect simplicity and frank cordiality, as back-ground for the relations of the workers among themselves, contributed to the attraction and success of the conferences.

Felt by everyone was a great desire to better understand the solutions to those economic and social problems presented by the present day condition of the enterprise and by the alarming rise in the cost of living with its distressing repercussions on the subsistence level of the working-man's family.

The subject for the year. - The labour leaders had chosen "The Canadian Worker Face to Face with Inflation» as subject. «We have not here», observed Father Jacques Cousineau, s.j., originator of these union summer sessions, « a question properly of union interest since, if you will, it does not concern the worker as producer in his relations with his employers. It is the consumer who is concerned here, that is, the worker who must provide shelter and food for himself as well as balance a budget. »

Group discussions. - The lectures finished - there were two a day - those present dispersed in groups of five or six to the grateful shade of the 
pines or the tamaracks above the cliff facing the river. And it was then that the work typical of these sessions really started.

Lecture notes in hand, mind directed to such and such an aspect of the problem interesting him, the worker of the Chemicals (Shawinigan) or he of Wabasso (Three Rivers) or he of the Empire Shirt (Louiseville) all had in common the enviable ability of plunging at once into the actual concrete facts of their respective difficulties. They could thus bring up in a simple natural manner, a deficiency they found in themselves, a regret, an ambition, or again a recent success in some section of their working environment.

After an hour of this fruitful exchange the secretary of the group would prepare a quick summary of the comments, objections, propositions suggested and pass them on to the lecturer in the round table discussion which followed.

Family budget. - Mr. Gérard Picard, general president of the Canadian and Catholic Confederation of Labour (C.T.C.C.) had just worked out for them the weekly, monthly and annual budget for a typical family of five (father, mother and three children) as at the beginning of the year 1948.

Housing, heat and light, food and clothing totalled $\$ 40$ by the week, $\$ 176$ by the month and $\$ 2,080$ by the year. These figures were based on the findings of the Dominion Statistician who, himself, testifying before the Price Inquiry Commission, declared, that they were too low.

Before the war, in August of 1939, an average family could procure the some 150 articles essential for living with a revenue of $\$ 1,450$.

At the beginning of January, 1948, the official compilations fixed at 151.3 the cost of living index, taking for base of 100 the month of August 1939.

Our workers then must compare this rise in the cost of living with the increase, more or less parallel, granted to them in the scale of their wages. And each, to do this, must take into account his own ideas and figures and family budget. And all, some with an income less than that mentioned above, had not always in their charge a family which could be classed as the typical family of five. There was, for example, the carpenter from Nicolet who had at home sixteen children, of whom fourteen were girls.
Cheap housing; Co-operative plan. - In a general group discussing cheap housing the lecturer, Monsieur Jean Desechamp, professor at the «Hautes Etudes Commerciales», was hard put to it to answer the flood of questions which his report provoked. It was the dream of each worker, his legitimate ambition to possess a home of his own, that one felt back of all the lively questionings, the demands for fuller information on the technical aspects of the co-operative plan and on the advantages to be derived from the recent Provincial Housing Act.

A delegate from Three Rivers, recounting the marvellous successes of Canon Chamberland's Building Co-operative, made many an eye glisten. Another, from Drummondville, brought his to the fore with legitimate pride. $\mathrm{He}$ was a member of the local co-operative and hoped to be in his house very soon. A delegation invited the lecturer to come and speak to their union on this splendid idea and help its members realize their dreams...

Consumer organization. - The same sustained attention, the same fundamental agreement on the other subjects! The purpose of economic life is consumption. But the consumer, who should dominate economic life, is in reality its plaything.

Faced with a strongly organized production and distribution are there any means for the consumer to influence prices? By union action, for example? The intervention of the State? By consumers' Leagues, price controls or Co-operatives? The discussion which ensued was guided by the expert hand of Monsieur Jean Marchand, secretary of the C.C.C.L., (C.T.C.C.) and went on in the course of the dinner which followed.

Reform of the enterprise. - Or else it was to the heart of the enterprise itself that the minds of those present were directed, interested in the extreme by a possible sharing of the workers in management, in profits and in ownership of the industry. Father Jacques Cousineau, moral advisor to the "Conseil Central» of Montreal, demonstrated the fitness and the justice of this profitsharing and enlarged upon different methods of applying it.

The evening forum. - In the peace of the approaching night as the cigarette smoke thickened, one and another of the delegates - a president of a union, perhaps, or a general agent - would be asked to share with his confreres in the circle, the successes and failures of the year's experiences and the plans for the future. 
There was always much to discuss and they went at it briskly and frankly, sometimes relating stories alive with interest. And because they came from different cities, different industries, the stories told by these leaders of men were never the same, except perhaps in the common qualities of determination, courage and unflagging devotion.

Experiences. - Such was the story of his life as a young worker, which a twenty-five old former jociste told us. Three years ago, well trained for action by the local study circles of the J.O.C., he decided, one day, to organize a union for the 150 employees of the factory where he worked. The reasons for doing so were excellent and pressing.

In three months he had rallied to the good cause more than two thirds of his working companions, obtained from Quebec the official incorporation of his union and commenced negotiations with the employer. Vain efforts! Pressures of all sorts - dismissals!

A conciliator came. Arbitration followed and a strike which lasted more than two months. There was active sympathy on the part of the population for the strikers and their young leadcr. Finally victory came and better working conditions for these 150 workers of whom a great number had families. And this thanks to the initiative, constancy and hard work of a young man of twenty-five years!

Another, dean, this one, of a chemical industry at Shawinigan, called to mind the sad lot of some of his comrades who, after years of work in an atmosphere charged with the fumes of mercuric oxide, were rendered unfit for any task; and were so affected in their nervous system and so deeply poisoned as to become a charge on their families. It would be the principal effort of their union this year to try and have improved the Workmen's Compensation Act in those clauses concerning industrial diseases.

The strong-minded . . . The revolutionaries? - Too many people still judge the worker, his leaders and his claims in a summary and often evtremely unjust manner. As soon as they hear of labour unions, of labour leaders, of wage adjustments, of collective agreements, of strikes, they see red and cry out against the growing domination of the working classes.

«Frankly, the working-man exaggerates », say these good people. "He never has enough. He will finish by managing everything. The rise in the cost of living? Well, it is the working-men who cause it with their incessant demands for higher wages. » And they go on from there. But they do not stop to think that there might be other causes for the crippling fluctuations in prices, for example, changes in the market, scarcity or abundance of production, the insatiable apetite of the cartels.

If we retain such a strong impression of our sojourn on the Island of St. Ignace in close contact with these leaders of our national unions, it is perhaps because of the fact that this important element of our French-Canadian population is weighty, reasonable and enlightened.

In listening to them discuss quietly among themselves the problems set by the lecture program, we found occasion to be proud and at the same time, to be reassured.

Whether they were from Montreal, Chambly, Three Rivers, Sorel, Nicolet, La Tuque, Shawinigan, Joliette, Drummondivelle, Quebec or Epiphany all showed a deep desire to work with all their might for the uplift of the working class of the country and a constant care to accomplish this high task with respect for order and justice.

May God bless the vow formulated so many times by the delegates and so dear to Father Cousineau - to realize soon a permanent Labour College where will be trained for our country its saviours. "To prevent the worker being condemned », in the words of Pope Pius the Twelfth, «to an economic servitude irreconciliable with the rights of his person».

(Ma Paroisse)

\section{Structural Reforms in Enterprise}

A booklet containing a reproduction of the articles published in the "Bulletin des relations industrielles" by Messrs. P.-E. Bolté, Marcel Clément and Gérard Dion will soon be obtainable at the Department of Industrial Relations of Laval University. 